\title{
The Use of Biodiesel Residues for Heat Insulating Biobased Polyurethane Foams
}

\author{
Nihan Özveren and M. Özgür Seydibeyoğlu \\ Department of Material Science and Engineering, İzmir Katip Çelebi University, Çiğli Main Campus, 35620 İzmir, Turkey \\ Correspondence should be addressed to M. Özgür Seydibeyoğlu; seydibey@gmail.com
}

Received 24 October 2016; Revised 14 December 2016; Accepted 18 December 2016; Published 18 January 2017

Academic Editor: Ahmad Shamiri

Copyright (c) 2017 Nihan Özveren and M. Özgür Seydibeyoğlu. This is an open access article distributed under the Creative Commons Attribution License, which permits unrestricted use, distribution, and reproduction in any medium, provided the original work is properly cited.

\begin{abstract}
The commercial and biobased polyurethane foams (PUF) were produced and characterized in this study. Commercial polyether polyol, crude glycerol, methanol-free crude glycerol, and pure glycerol were used as polyols. Crude glycerol is byproduct of the biodiesel production, and it is a kind of biofuel residue. Polyol blends were prepared by mixing the glycerol types and the commercial polyol with different amounts, $10 \mathrm{wt} \%, 30 \mathrm{wt} \%, 50 \mathrm{wt} \%$, and $80 \mathrm{wt} \%$. All types of polyol blends were reacted with polymeric diphenyl methane diisocyanates (PMDI) for the production of rigid foams. Thermal properties of polyurethane foams are examined by thermogravimetric analysis (TGA) and thermal conductivity tests. The structures of polyurethane foams were examined by Fourier Transformed Infrared Spectroscopy (FTIR). Changes in morphology of foams were investigated by Scanning Electron Microscopy (SEM). Mechanical properties of polyurethane foams were determined by compression tests. This study identifies the critical aspects of polyurethane foam formation by the use of various polyols and furthermore offers new uses of crude glycerol and methanol-free crude glycerol which are byproducts of biodiesel industry.
\end{abstract}

\section{Introduction}

Polyurethanes (PU), which are in the family of polymers, were first investigated by Otto Bayer [1]. Polyurethanes, also referred to as urethanes, are characterized by the urethane linkage:

$$
\text { -NH-C (=O) -O- }
$$

The linkage is formed by the reaction of organic isocyanate groups with hydroxyl groups, which are called polyol, as shown by the model reaction:

$$
\mathrm{R}-\mathrm{NCO}+\mathrm{R}^{\prime}-\mathrm{OH} \longrightarrow \mathrm{R}-\mathrm{NH}-\mathrm{C}(=\mathrm{O})-\mathrm{O}-\mathrm{R}^{\prime}
$$

Polyurethanes are classified into five groups: CASE (Coatings, Adhesives, Sealants, and Elastomers), synthetic leathers, biomedical, thermoplastic polyurethanes (TPU), and foams [2-25].

Polyurethane foam is the largest segment in the foam industry. Polyurethane foams are block polymers that are prepared by the reaction of polyols with diisocyanates in the presence of catalysts, surfactants, and blowing agents. The characteristics of polyurethane foams are changed with the properties of reactants, such as molecular weight and functionality of polyols [26]. According to these properties, polyurethane foams are classified into two categories: flexible and rigid foams.

Rigid polyurethane foams are prepared at ambient temperature without heating and consist of high percent of closed cells and have unique characteristics. They are used as thermal insulation products to energy savings on the earth, such as refrigerators, freezers, refrigerated trucks, refrigerated containers, refrigerated warehouses, building and construction, chemical and petrochemical plants, water heaters, portable ice boxes, and insulating bottles [27].

In recent years, the use of biobased polyol has boomed in polyurethane industry and many commercial applications are arising. The researchers are focused on plant based polyols for renewable resources. The oils are extracted from various plants and converted to polyols with certain reactions [28$34]$. Two types of polyols, castor oil and soy polyol, are commonly used [35]. Soy polyol based polyurethanes are limited 
since they have lower mechanical properties and odor arising during processing. There are some studies to reinforce biobased polyurethanes to overcome the low mechanical properties with glass fiber and natural fibers like lignin. There have been some studies to synthesize polyurethanes from lignin to utilize lignin and to make green materials [36].

Biodiesel is an alternative and renewable fuel for diesel engines and it is also nontoxic and biodegradable. It is also used directly in most diesel engines without requiring extensive engine modifications [37]. Biodiesel is produced by transesterification reaction with fat or oil and alcohol, ethanol or methanol, in the presence of a catalyst, such as potassium hydroxide $(\mathrm{KOH})$ or sodium hydroxide $(\mathrm{NaOH})$. The product of the reaction is fatty acid methyl esters (FAME) which are known as biodiesel and crude glycerol which is coproduct $[37,38]$.

Crude glycerol is a kind of solution which includes glycerol (50-60\% purity), methanol, catalyst, soap, salt, and water. Firstly, methanol is removed from the crude glycerol for reuse in the production. From methanol-free crude glycerol (80-90\% purity), other components are separated with some purification techniques, and lastly pure glycerol is obtained [39-44].

In this study, biodiesel residues such as crude glycerol, methanol-free crude glycerol, and pure glycerol were used in the polyether polyol formulation at different percentages. The effect of glycerol addition to polyether polyol on the properties of polyurethane foams and structure was investigated by using thermal conductivity measurements, compression test, Fourier Transform Infrared Spectroscopy (FTIR), Thermogravimetric Analysis (TGA), and Scanning Electron Microscopy (SEM). This study demonstrated the critical aspects of polyurethane foam formation by the use of various polyol blends and furthermore offers new uses of crude glycerol, methanol-free crude glycerol, and pure glycerol which are coproducts of biodiesel industry.

\section{Experimental}

2.1. Materials. Four different types of polyurethane foams were prepared with one-step foaming method by cup foaming. Polyether polyol, crude glycerol, methanol-free crude glycerol, pure glycerol, and PMDI are the main raw materials. Other additives for the PUF preparation are two types of catalysts, surfactant and pure water as a blowing agent. Polyether polyol (CPP) was provided from Oltchim S.A. (Valcea, Romania) with the hydroxyl number of $400 \mathrm{mg} \mathrm{KOH} / \mathrm{g}$ and functionality value of 4.5 . It has a commercial name of Petol PS 400-4G.

Crude glycerol (CG) and methanol-free crude glycerol (MFCG) were obtained from DB Agricultural Energy Co. (Izmir, Turkey) with the hydroxyl numbers calculated (ASTM D 4274-05, Test Method B) as $1850 \mathrm{mg} \mathrm{KOH} / \mathrm{g}$ and $1770 \mathrm{mg} \mathrm{KOH} / \mathrm{g}$, respectively. Crude glycerol contains approximately $50.0 \%$ glycerol, $25.0 \%$ water, $16.5 \%$ methanol, $5.0 \%$ soap, $3.0 \%$ sodium hydroxide, and $0.5 \%$ salt. Methanol-free crude glycerol includes $84.8 \%$ glycerol, $7.7 \%$ water, $4.5 \%$ soap, $2.3 \%$ sodium hydroxide, $0.5 \%$ salt, and $0.2 \%$ methanol. These contents were measured by using Headspace Gas

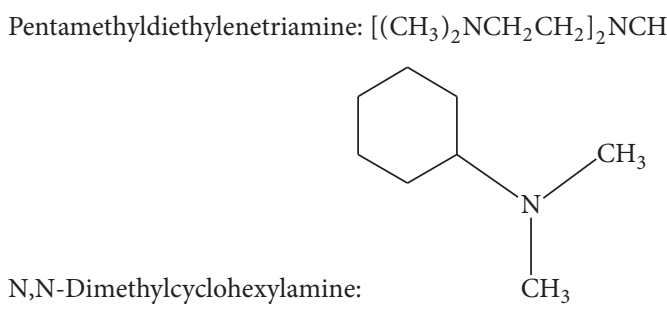

SCHEME 1

Chromatography Mass Spectroscopy (HS-GCMS), Agilent Technologies 7697A Headspace 7890A GC System.

Pure glycerol was provided from Akdeniz Kimya A.S. (İzmir, Turkey) with the hydroxyl number calculated (ASTM D 4274-05, Test Method B) as $1865 \mathrm{mg} \mathrm{KOH} / \mathrm{g}$.

Polymeric MDI (PMDI) was obtained from Bayer Material Science AG (Leverkusen, Germany) with 31.5\% NCO content. The commercial name of PMDI is Desmodur 44V20L.

Two types of tertiary amine catalysts were used in this research; pentamethyldiethylenetriamine and N,N-dimethylcyclohexylamine are taken from Evonik Industries AG (Essen, Germany). Their commercial names are Tegoamin PMDETA and Tegoamin DMCHA, respectively.

Silicon surfactant was obtained from Air Products Chemicals (Hamburg, Germany) and it has a commercial name of Dabco DC193. Chemical formulas of catalysts are given in Scheme 1.

Water was used as a blowing agent in this study. For all samples, the amount of water was equal although the crude glycerol and methanol-free crude glycerol include water. The foaming reaction is exothermic and excess amount of water evaporated. For CG, methanol also evaporated during the reaction. These evaporations were undesired gas formations for this study.

2.2. Preparation of Polyurethane Foams. Polyurethane foam with CPP was prepared by mixing approximately $100 \mathrm{wt} \%$ polyether polyol, $1 \mathrm{wt} \%$ surfactant, $0.4 \mathrm{wt} \%$ catalyst, $0.4 \mathrm{wt} \%$ cocatalyst, and $2.5 \mathrm{wt} \%$ water at the beginning forming the premixture. Then PMDI was added, about $102 \mathrm{wt} \%$, at room temperature with mixing for the reaction occurring. Index of 1 is appropriate for solvent systems. For waterborne formulations, an index greater than 1 is recommended due to the competing reaction of diisocyanate and water. In this study, the water was used as blowing agent. In the reaction, we assumed that if the amount of polyol was 100, the amount of diisocyanate was 102 due to the amount of water being about $2 \mathrm{wt} \%$. Molecular ratio of isocyanate to hydroxyl groups ( $\mathrm{NCO} / \mathrm{OH}$ ratio) was calculated with these equations that were given above and kept at 1.08 for all samples (Table 1). This ratio was also greater than 1 . In addition, higher indexing will promote higher crosslinking, higher strength, and better chemical resistance.

$$
\mathrm{OH} \text { number }=\frac{56.1 \mathrm{~g} / \mathrm{mole} \times 1000 \mathrm{mg} / \mathrm{g}}{\mathrm{OH}_{\text {eq.w }}} .
$$


TABLE 1: Preparation amounts of PUF samples.

\begin{tabular}{|c|c|c|c|c|c|}
\hline & & $\mathrm{CPP}$ & CG & MFCG & PG \\
\hline \multirow{6}{*}{ Polyol mixture } & Polyether polyol & $100 \%$ & $90 \%, 70 \%, 50 \%, 20 \%$ & $90 \%, 70 \%, 50 \%, 20 \%$ & $90 \%, 70 \%, 50 \%, 20 \%$ \\
\hline & Glycerol & & $10 \%, 30 \%, 50 \%, 80 \%$ & $10 \%, 30 \%, 50 \%, 80 \%$ & $10 \%, 30 \%, 50 \%, 80 \%$ \\
\hline & Surfactant & $1 \%$ & $2 \%$ & $1,5 \%$ & $1 \%$ \\
\hline & Catalyst & $0,4 \%$ & $0,4 \%$ & $0,4 \%$ & $0,4 \%$ \\
\hline & Cocatalyst & $0,4 \%$ & $0,4 \%$ & $0,4 \%$ & $0,4 \%$ \\
\hline & Water & $2,5 \%$ & $2,5 \%$ & $2,5 \%$ & $2,5 \%$ \\
\hline Diisocyanate & $\mathrm{NCO} / \mathrm{OH}$ ratio & 1,08 & 1,08 & 1,08 & 1,08 \\
\hline Mixing speed & $\mathrm{rpm}$ & 1500 & 1000 & 1500 & 1500 \\
\hline Mixing time & (s) & 12 & 8 & 12 & 15 \\
\hline
\end{tabular}
is 400 .

$\mathrm{OH}$ number is written in TDS and for $\mathrm{CPP}, \mathrm{OH}$ number

$$
\begin{aligned}
400 & =\frac{56.1 \mathrm{~g} / \mathrm{mole} \times 1000 \mathrm{mg} / \mathrm{g}}{\mathrm{OH}_{\text {eq.w }}} \\
\mathrm{OH}_{\text {eq.w }} & =\frac{56100}{400}=140.25 \\
\mathrm{NCO}_{\text {eq.w }} & =\frac{\mathrm{MW} \times 100}{\% \mathrm{NCO} \text { content }} .
\end{aligned}
$$

$\%$ NCO content is written in TDS and for PMDI, NCO content is $31.5 \%$.

$$
\begin{aligned}
\mathrm{NCO}_{\text {eq.w }} & =\frac{4200}{31.5} \cong 133.34 \\
\frac{\mathrm{NCO}}{\mathrm{OH}} \text { Index } & =\frac{\mathrm{Q}_{\mathrm{NCO}} \times \mathrm{OH}_{\text {eq.w }}}{\mathrm{Q}_{\mathrm{OH}} \times \mathrm{NCO}_{\text {eq.w }}} \\
\frac{\mathrm{NCO}}{\mathrm{OH}} \text { Index } & =\frac{102 \times 140.25}{100 \times 133.34} \cong 1.08 .
\end{aligned}
$$

$\mathrm{OH}$ numbers of other samples, which were mixture of $\mathrm{CPP}$ and glycerol types, were calculated with this equation:

$$
\begin{aligned}
\mathrm{OH} \text { number }_{\text {mix }}= & \left(\mathrm{OH} \text { number }_{A} \times \mathrm{wt} \% A\right) \\
& +\left(\mathrm{OH} \text { number }_{B} \times \mathrm{wt} \% B\right) .
\end{aligned}
$$

Another type of polyurethane foams, with CG, was prepared by mixing polyether polyol and crude glycerol at different amounts, $90 \%-10 \%, 70 \%-30 \%, 50 \%-50 \%$, and $20 \%$ $80 \%$, respectively. Then $2 \%$ surfactant, $0.4 \%$ catalyst, $0.4 \%$ cocatalyst, and $2.5 \%$ water were added to the polyol mixture. For these samples, the amount of surfactant was higher than the others because of the methanol content. Undesired gas occurred during the reaction and damaged the closed cells. The surfactant protects the cells to be stable. After forming the premixture, $\mathrm{PMDI}$ was added at the same $\mathrm{NCO} / \mathrm{OH}$ ratio as commercial PUF and calculated amounts.

Third type of polyurethane foams, with MFCG, was prepared by mixing polyether polyol and methanol-free glycerol at different amounts, 90\%-10\%, 70\%-30\%, 50\%-50\%, and $20 \%-80 \%$, respectively. Then $1.5 \%$ surfactant, $0.4 \%$ catalyst, $0.4 \%$ cocatalyst, and $2.5 \%$ water were added to the polyol mixture. For these samples, the amount of surfactant was higher than CPP and PG samples due to the impurities. The surfactant supports the cells to be stable. After forming the premixture, $\mathrm{PMDI}$ was added at the same $\mathrm{NCO} / \mathrm{OH}$ ratio as commercial PUF and calculated amounts.

The last type of polyurethane foams, with PG, was prepared by mixing polyether polyol and pure glycerol at different amounts, $90 \%-10 \%, 70 \%-30 \%, 50 \%-50 \%$, and $20 \%$ $80 \%$, respectively. Then $1 \%$ surfactant, $0.4 \%$ catalyst, $0.4 \%$ cocatalyst, and $2.5 \%$ water were added to the polyol mixture. After forming the premixture, PMDI was added at the same $\mathrm{NCO} / \mathrm{OH}$ ratio as commercial PUF and calculated amounts.

All samples were mixed with the mechanical mixer (Velp Scientifica, Overhead Stirrer, 0-2000 rpm) at $1500 \mathrm{rpm}$ for about 12 seconds, with crude glycerol mixing speed of $1000 \mathrm{rpm}$ due to rapid foaming as a consequence of methanol presence. Mixing times were different from each other, since their cream times, the beginning of the foam reaction, are different.

\subsection{Methods}

2.3.1. Fourier Transform Infrared Spectroscopy (FTIR) Analysis. FTIR analysis was conducted with Thermo Scientific, Nicolet iS5 FT-IR Spectrometer (ATR Mode), with 4000 and $400 \mathrm{~cm}^{-1}$ scan range to investigate the polyurethane structure and to determine if there is any free NCO in the polyurethane foams. Firstly, FTIR graphs of all samples were drawn on excel one by one. The peak intensities were written on the graphs. Then, the graphs were combined according to glycerol types.

2.3.2. Mechanical Properties: Compression Testing. Compressive strength of PU foams was measured in accordance with BS EN ISO 844:2009. The dimensions of the samples were right prism with $50 \times 50 \times 50 \mathrm{~mm}$. According to this method for $10 \%$ deformation, the maximum compression strength value of the samples was measured with Shimadzu AGS-X $5 \mathrm{kN}$ testing machine.

2.3.3. Scanning Electron Microscopy (SEM). Scanning electron microscopy, Quanta 400F Field Emission SEM, was used at $20 \mathrm{kV}$. The samples were coated with gold in order to have conductive samples to measure and avoid charging. 
2.3.4. Thermal Conductivity. Thermal conductivity of the samples was measured with C-Therm TCi Thermal Conductivity Analyzer. Each sample was measured five times to find the average value at $30^{\circ} \mathrm{C}$. All samples, whose height is $1,5 \mathrm{~cm}$ and diameter is $7 \mathrm{~cm}$ (circle shape), of smooth surface were measured to uniform results.

2.3.5. Thermogravimetric Analysis (TGA). Perkin Elmer Diamond TG/DTA was used for TGA analysis. The measurements were done from $30^{\circ} \mathrm{C}$ to $630^{\circ} \mathrm{C}$ with a heating rate of $10^{\circ} \mathrm{C} / \mathrm{min}$ under nitrogen atmosphere at atmospheric pressure. The analysis was used to determine the solid content left when the polymer was heated up to $630^{\circ} \mathrm{C}$. The weights of samples were between $3 \mathrm{mg}$ and $7 \mathrm{mg}$.

\section{Results and Discussions}

3.1. Fourier Transform Infrared Spectroscopy (FTIR). FTIR was used to investigate changes of polyurethane polymerization with different glycerol types and different amounts. The isocyanate absorption band (-NCO vibration) is assigned at $2270 \mathrm{~cm}^{-1}$. This absorbance can be used to monitor the isocyanate group conversion during the polymerization. The hydrogen bonded - $\mathrm{NH}$ stretching vibration associated with the urethane group is dominated between 3380 and $3360 \mathrm{~cm}^{-1}$. $-\mathrm{OH}$ stretching is also at 3600 and $3300 \mathrm{~cm}^{-1}$. However, O-H vibration is larger than $\mathrm{N}-\mathrm{H}$ vibration. All results were narrower so the peaks were examined as $\mathrm{N}-\mathrm{H}$ vibration. Another important vibration is urethane $(-\mathrm{C}=\mathrm{O})$ vibration assigned at $1720 \mathrm{~cm}^{-1}$ (carbonyl region). Firstly, FTIR graphs of all samples were drawn on excel one by one. The peak intensities were written on the graphs. Then, the graphs were combined according to glycerol types.

Figure 1 shows that the -NCO vibration peaks are neglected at $2270 \mathrm{~cm}^{-1}$ and because of that the peak of CPP is higher than the samples of CG. This means there is no excess isocyanate in the polymerization. And then, for the urethane vibration, CG-10 has the maximum value which is $7,87 \times 10^{-2}$ compared to the other foams. This type of PUF has also the maximum values for the $-\mathrm{NH}$ stretching vibration at approximately $3400-3300 \mathrm{~cm}^{-1}$. CG-30 has the similar values of CG-10, 1,59 $\times 10^{-2}$ and $1,58 \times 10^{-2}$. For these samples, $-\mathrm{NH}$ stretching vibration and urethane vibration values decrease with the CG content increases, due to the methanol content. Undesired gas occurred during the process and caused damage to the crosslinking structure.

The -NCO vibration peaks are similar for the all samples which included methanol-free crude glycerol and they are lower than the commercial one, CPP. This means there is a small amount of excess isocyanate in the polymerization. For the urethane vibration, MFCG-30 and MFCG-80 have the maximum values compared to the other foams, respectively, $9,21 \times 10^{-2}$ and $5,45 \times 10^{-2}$. On the other hand, for the $\mathrm{NH}$ stretching MFCG-80, 5,91 $\times 10^{-2}$, has higher value than MFCG-30, 2,59 $\times 10^{-2}$ (Figure 2). It is expected that urethane vibration and $-\mathrm{NH}$ stretching increase with the MFCG content increases, but the results revealed that this did not happen. The urethane vibration decreases and -NH stretching

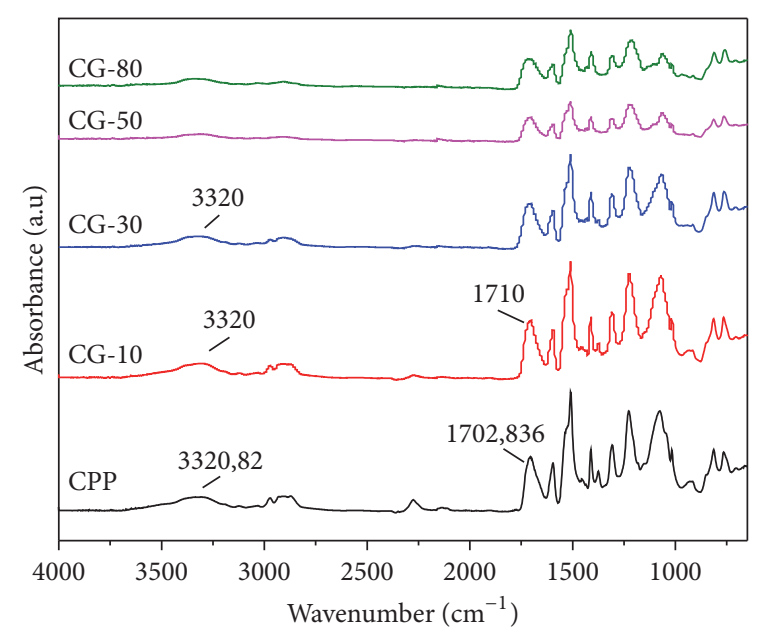

FIGURE 1: FTIR results of PUF samples with crude glycerol.

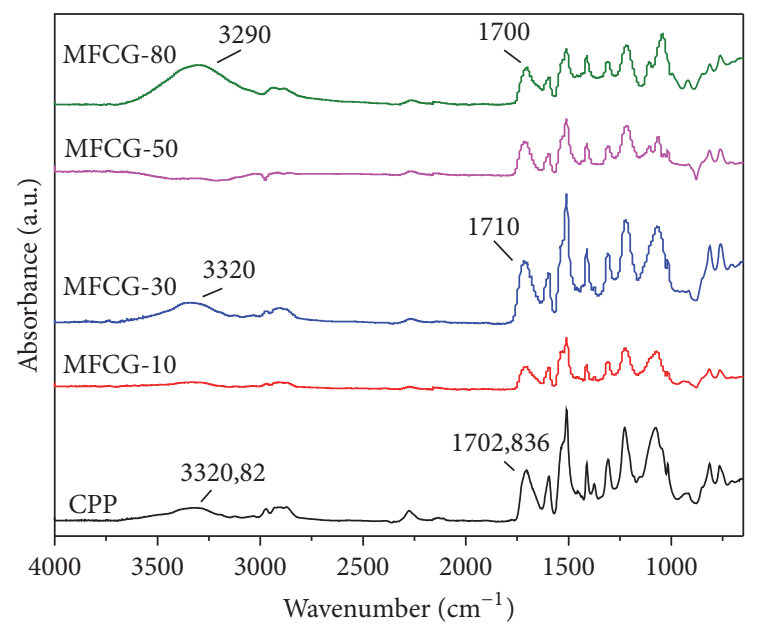

FIGURE 2: FTIR results of PUF samples with methanol-free crude glycerol.

increases with the MFCG content increases. This could be the outcome of improper mixing with mechanical mixer.

In Figure 3, the - NCO vibration peaks are shown at $2270 \mathrm{~cm}^{-1}$ and PG-30 $\left(2,71 \times 10^{-2}\right)$ has the maximum values. During the polymerization, there is an excess isocyanate. It could be the mixing error. In addition, for the urethane vibration PG-80 has the maximum values, $12,9 \times 10^{-2}$, compared to the other foams. PG-50 $\left(9,32 \times 10^{-2}\right)$ has also similar values to PG-80. These amounts of PUF have also the maximum values for the $-\mathrm{NH}$ stretching vibration, PG-80 and PG-10, $4,12 \times 10^{-2}$ and $2,32 \times 10^{-2}$, respectively. Both $-\mathrm{NH}$ stretching and urethane vibration values increase with the PG content increases; it is also expected for the purity of glycerol.

Araújo et al. (2005) studied the flexible polyurethane foams using biopitch which is obtained by the distillation of the tar recovered during Eucalyptus charcoal production [45]. In FTIR results, the hydroxyl bond overlaps with the $\mathrm{NH}$ bonds at $3350 \mathrm{~cm}^{-1}$ so biopitch $\mathrm{OH}$ groups are unreacted because of their low accessibility. On the other hand, in FTIR 


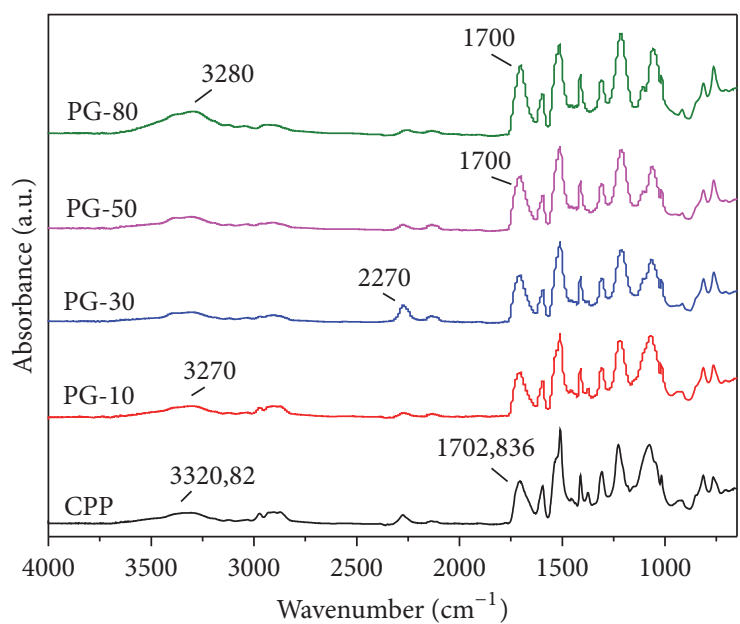

FIGURE 3: FTIR results of PUF samples with pure glycerol.

results for all samples (crude glycerol, methanol-free crude glycerol, and pure glycerol) - $\mathrm{NH}$ vibrations are lower so there are no unreacted $\mathrm{OH}$ groups.

Piszczyk et al. (2012) researched the preparation of rigid polyurethane-polyglycerol nanocomposite foams [46]. The polyether polyol and polyglycerol were mixed in various ratios (35\% and 70\%). In the FTIR graphs, at 2850 and $2924 \mathrm{~cm}^{-1}$ the higher peaks are assigned to the terminal vibrations of $\mathrm{C}-\mathrm{H}$ bonds from $\mathrm{CH}_{2}$ groups in the aliphatic chains. The higher intensity of those bands can be assigned to the higher content of the polyglycerol. However, for the graphs of all samples, which were prepared with crude glycerol, methanol-free crude glycerol, and pure glycerol, the intensities of those bands decrease with the amount of glycerol types increasing, due to the simpler structure compared to glycerol.

FTIR results gave general information about chemical bonding of foams. All peaks, -NCO, urethane, and - $\mathrm{NH}$ vibrations, are also shown in the spectrums. According to the results, CG-10, CG-30, MFCG-80, MFCG-30, PG-80, and PG-10 are similar to CPP.

3.2. Mechanical Properties: Compression Testing. A compression test determines behavior of materials under crushing loads. The specimen is compressed and deformation at various loads is recorded. Compressive stress and strain are plotted as a stress and strain diagram.

Compressive strength of PU foams was measured in accordance with BS EN ISO 844:2009. The compressive strength of PU foams strongly depends on their apparent density. In this method, the apparent density is not measured; only dimensions are important. The dimensions of the samples were right prism with $50 \times 50 \times 50 \mathrm{~mm}$. The compression direction was the opposite of foam rise direction.

The results of the compression test are given in Table 2.

The compressive strength values were increased with increasing glycerol content for both PG and MFCG samples because the purity of glycerol was better and the number of closed cells increased. However, compression strength values
TABLE 2: Compression strength values of PUF samples.

\begin{tabular}{lc}
\hline Samples & Compressive strength $[\mathrm{MPa}]$ \\
\hline CG-10 & $0,16973 \pm 0,01$ \\
CG-30 & $0,17802 \pm 0,02$ \\
CG-50 & $0,13696 \pm 0,01$ \\
CG-80 & $0,10835 \pm 0,02$ \\
\hline MFCG-10 & $0,10038 \pm 0,01$ \\
MFCG-30 & $0,11013 \pm 0,01$ \\
MFCG-50 & $0,15761 \pm 0,01$ \\
MFCG-80 & $0,20306 \pm 0,03$ \\
\hline PG-10 & $0,16180 \pm 0,05$ \\
PG-30 & $0,18440 \pm 0,03$ \\
PG-50 & $0,18965 \pm 0,04$ \\
PG-80 & $0,24522 \pm 0,05$ \\
\hline CPP & $0,13000 \pm 0,02$ \\
\hline
\end{tabular}

were decreased with increasing glycerol content until CG-30; according to FTIR results (Figure 1), urethane vibration is maximum. Due to irregular cells which are shown in SEM photos (Figure 4), higher $\mathrm{CO}_{2}$, and gas formation while preparing PUF, CG samples are weaker than the others. For all samples, compressive strength and the rigidity of foams increased with increasing purity of glycerol. These results are very important for the use of glycerol types, especially crude glycerol (CG) and methanol-free crude glycerol (MFCG).

Zlatanić et al. (2004) synthesized the polyols based on mid-oleic sunflower, canola, soybean, sunflower, corn, and linseed oils [47]. They determined that the mechanical strength increased with the hydroxyl number of the polyols. In this study, the hydroxyl number also increases with the purity of glycerol. Therefore, the compressive strength is increased.

Luo et al. (2013) researched the rigid polyurethane foams from biopolyols which was prepared with crude glycerol (22,9\% glycerol, $10,9 \%$ methanol) [48]. The compressive strength of PUF was determined as $0,1845 \mathrm{MPa}$; it is higher than the commercial PUF. On the other hand, this value is less than PG-50 and PG-80 and MFCG-80. In addition, the compression value is higher than all samples with CG, so the methanol content is $16,5 \%$ and crude glycerol was reacted with sulfuric acid in the biopolyols production. As a result of this, the compressive strength of the rigid polyurethane foam, produced from biopolyols with MFCG, will be higher.

Dang et al. (2016) used waste cooking oil and postconsumer PET bottles in the production of biodiesel and rigid polyurethane foams [44]. The compressive strength values were determined from 0,2359 to $0,2999 \mathrm{MPa}$ with increasing the crude glycerol content. In this study, the compressive strength of samples was measured from 0,10038 to $0,20306 \mathrm{MPa}$ for MFCG and from 0,1618 to $0,24522 \mathrm{MPa}$ for PG. These results also showed that the compressive values increased with increasing the glycerol content. However, for CG samples the compressive strength values were examined from 0,16973 to $0,10835 \mathrm{MPa}$. After CG-30, the compressive strengths were decreased. This could be explained by the increased amount of methanol in crude glycerol. During the 

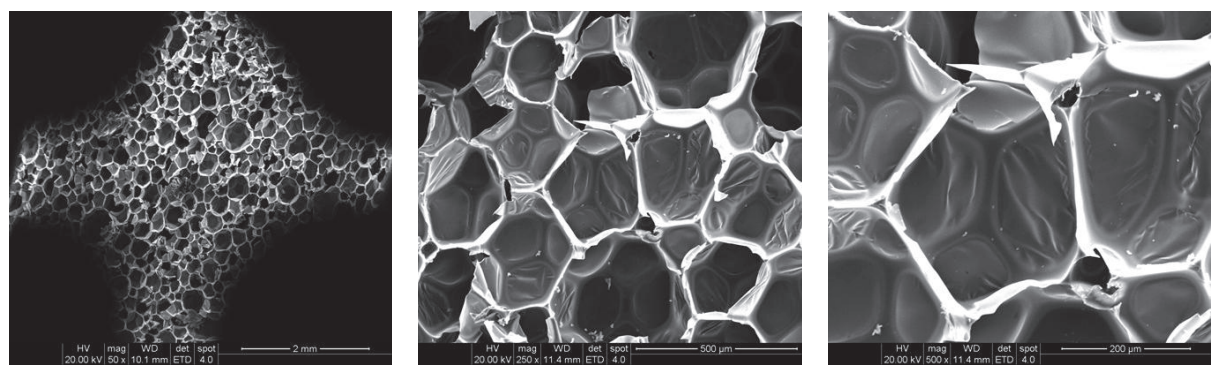

(a)
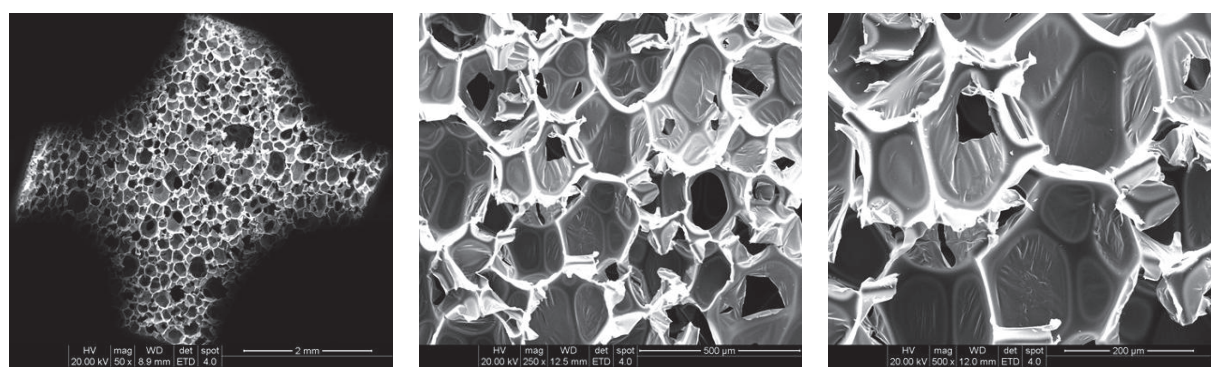

(b)
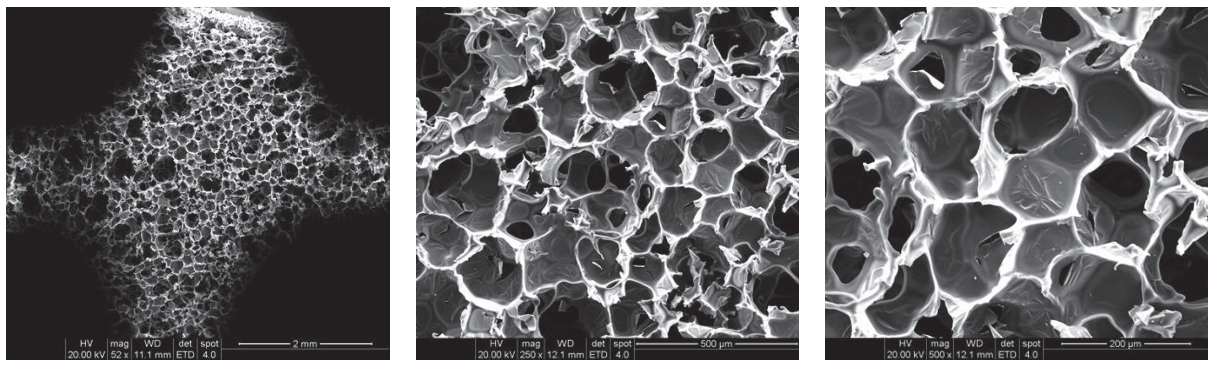

(c)
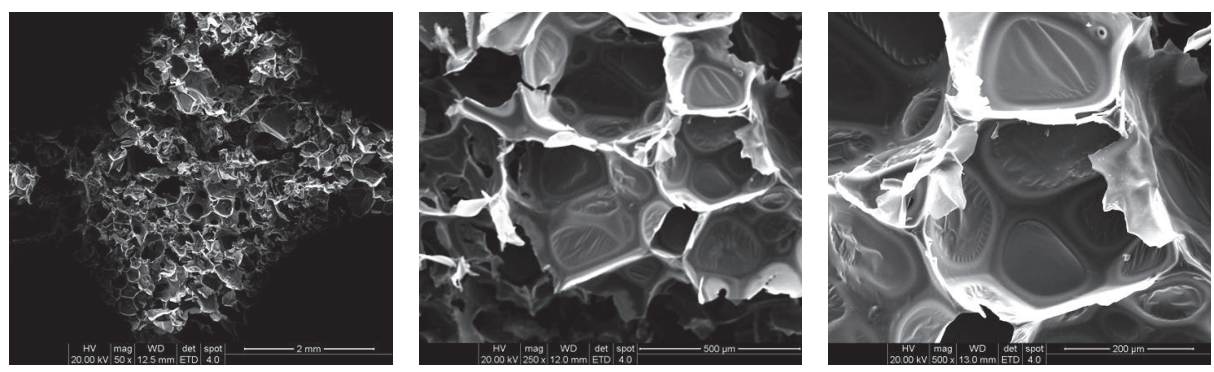

(d)
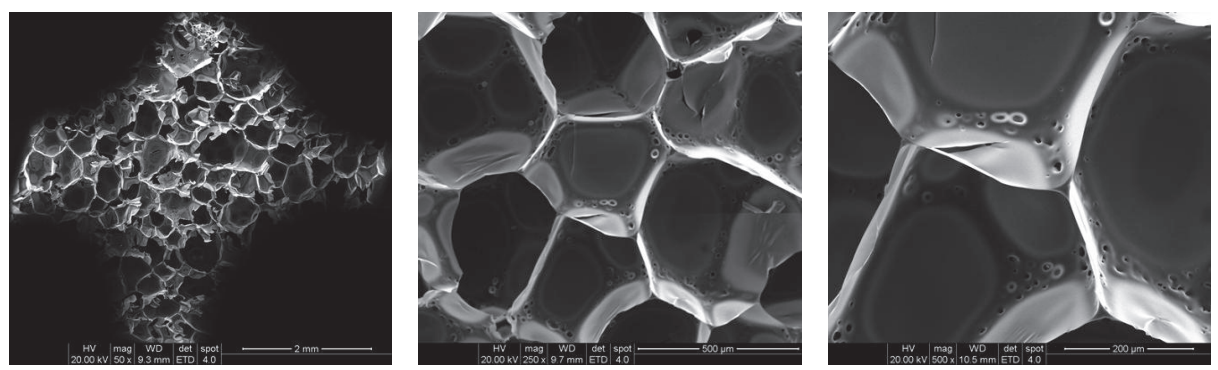

(e)

FIGURE 4: SEM photos of CG samples ((a) 10\%, (b) 30\%, (c) 50\%, (d) $80 \%$, and (e) CPP). 
preparation of the sample of PUF with CG, gas formation occurred due to methanol, except $\mathrm{CO}_{2}$. This gas formation affected the structures of CG samples.

3.3. Scanning Electron Microscopy (SEM). The foam insulation can be categorized into two different types: closed cell and open cell. Firstly, closed cell foams are much denser than open cell ones. They have a smaller, more compact cell structure, filled with inert gas. They feature better insulation because of this resistance and are also more resistant to water degradation or penetration, which includes moisture buildup. Moisture can eventually attract bacterial growth, promoting mold, which can eat away at wood and compromise structural integrity. This strength not only helps to insulate buildings and appliances, but also can strengthen walls to which it is applied. Another type of foam is open cell where the cells are not completely closed. Installation is similar to that of closed cells, but the effects are different, not providing any type of water vapor barrier and lower noise frequency ranges. Its heat resistance level is lower, which can cause insulation failures in extreme temperatures.

The micrographs show the sizes and shapes of cell foams. The close cell structure is confirmed by the morphological analysis performed by SEM in Figures 4, 5, and 6 with enlargements of 50, 250, and 500 times, respectively. The structure of CPP is compact and complete. For samples with CG, PUF has lots of fragments and the inner structure was heavily damaged, and the cell size measures about $125 \mu \mathrm{m}$ to $290 \mu \mathrm{m}$. For samples with MFCG, cell sizes are measured between $125 \mu \mathrm{m}$ and $300 \mu \mathrm{m}$. In addition, for samples with PG, cell sizes are between $85 \mu \mathrm{m}$ and $200 \mu \mathrm{m}$. According to CPP, whose cell size is between $180 \mu \mathrm{m}$ to $375 \mu \mathrm{m}$, all samples are better for insulation. However, for all types of glycerol, it can be observed that the close cell structure is damaged with increasing glycerol content in commercial polyether polyol. The hydroxyl numbers of glycerols are greater by 3,5 times than the commercial polyol. Therefore, the mixing time and creaming time are also greater. There has been damage in the structure of closed cells due to glycerol content. $\mathrm{Hu}$ and $\mathrm{Li}$ also determined that the PUF had longer cream time due to high hydroxyl number of polyols [42]. Then, Dang et al. (2016) examined that the cream time increased with increasing the amount of crude glycerol [44]. They also highlighted that the glycerol caused secondary hydroxyl groups and increased viscosity and hydroxyl number of polyols. In addition, the cream time increased with increasing the required amount of PMDI in the same index.

Septevani et al. (2015) produced rigid polyurethane foam by using polyether polyol and palm kernel oil based polyester polyol [49]. They prepared PUF with different contents of palm based polyol (10\%, 20\%, 30\%, and 50\%) and determined the average diameter of the cell as $448,480,739$, and $748 \mu \mathrm{m}$, respectively. In this research, diameter of closed cells for all samples (CG, MFCG, and PG) was measured smaller than other samples which were produced with palm based polyol.

The properties of the liquefied products from mountain pine beetle-infested barks, which were applied as polyols, and the resulting bark-containing PU foams were investigated by Zhao et al. (2012) [43]. The polyurethane foams were prepared in different liquefied bark/PMDI ratios. They determined less uniform cell and more distorted closed cell structures with the ratio increased. In this study, the closed cell structures were also distorted with the amount of glycerol contents increased.

3.4. Thermal Conductivity. Thermal conductivity is one of the most important properties for the insulation materials. Best insulation materials have the lowest thermal conductivity. Dry stagnant gas is one of the best insulating materials. The insulating properties of commercially available insulating materials are determined by the amount of gas held inside the material and the number of gas pockets. Therefore, the higher the number of cells and the smaller the size, the lower the thermal conductivity of such insulating material. These cells should not be interlinked, as this will allow convection of heat.

PUF is effective as an insulator because it has a high proportion (nearly 90\%) of nonconnected closed microcells, filled with inert gas. In this project, inert gas is carbon dioxide. Thermal conductivity values are measured with the device which uses a one-sided, interfacial, heat reflectance sensor that applies a momentary, constant heat source to the sample.

The thermal conductivity also depends on the apparent density of foams. However, the apparent density of the samples was not measured during this study. Therefore, comparison was not done. The thermal conductivity values were compared with only cell size and shape, SEM photos.

The cell structures in Figures 4, 5, and 6, for all types of glycerol, mixing ratio at $10 \%$, are similar to the commercial one. The number of undamaged, closed cells is increased with the purity, so the unexpected gas formation decreases. As a result of these, the thermal conductivity decreases with the high number of cells and smaller cell size.

In Figure 7, thermal conductivity values are shown for all samples. PG-10 has the minimum value of $0,028 \mathrm{~W} / \mathrm{m} \cdot \mathrm{K}$. SEM photos supported that kind of PUF being close to the commercial one. Secondly, thermal conductivity of CG-30 is $0,029 \mathrm{~W} / \mathrm{m} \cdot \mathrm{K}$. These two types of PUF are close to the commercial one. Finally, four other samples have the same thermal conductivity value as the commercial polyurethane foam, $0,030 \mathrm{~W} / \mathrm{m} \cdot \mathrm{K}, \mathrm{MFCG}-10$ and MFCG-50 and CG-10 and PG-30.

Arduini-Schuster et al. (2015) researched the experimental characterization and theoretical modeling of the thermal conductivity of foams [50]. Two different foams were studied, extruded polystyrene foam (XPS) and polyurethane foam (PUF). Thermal conductivity values were measured for XPS and PUF as $0,0331 \pm 0,0017$ and $0,0267 \pm 0,0013 \mathrm{~W} / \mathrm{m} \cdot \mathrm{K}$, respectively. These values are total of radiative thermal conductivity, gaseous thermal conductivity, and solid thermal conductivity values of samples. On the other hand, thermal conductivities of PG-10 and CG-30 are similar to measured PUF, despite nonaccurate measurement.

Piszczyk et al. (2014) synthesized rigid polyurethane foams from polyglycerol-based polyol and researched their cellular structures, the values of thermal stability, and thermal conductivity [51]. Two types of polyglycerol were used with various amounts $(35 \%, 70 \%)$. The thermal conductivity 

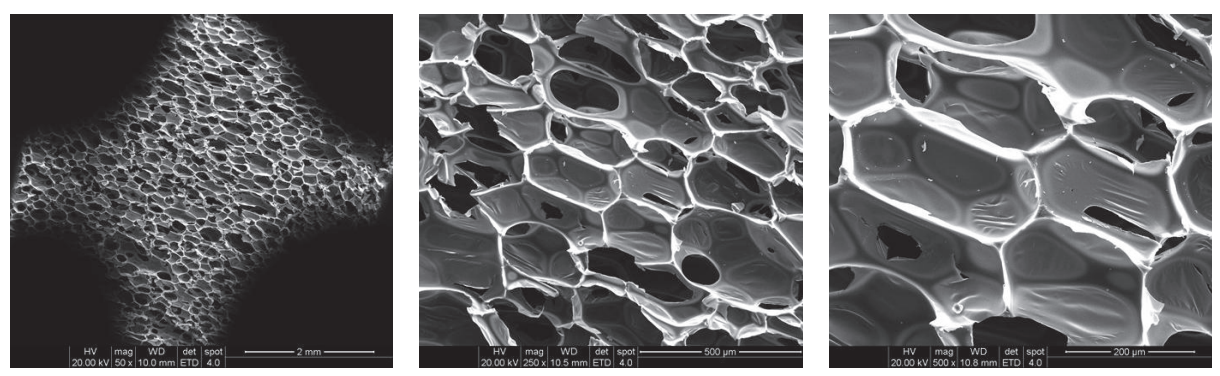

(a)
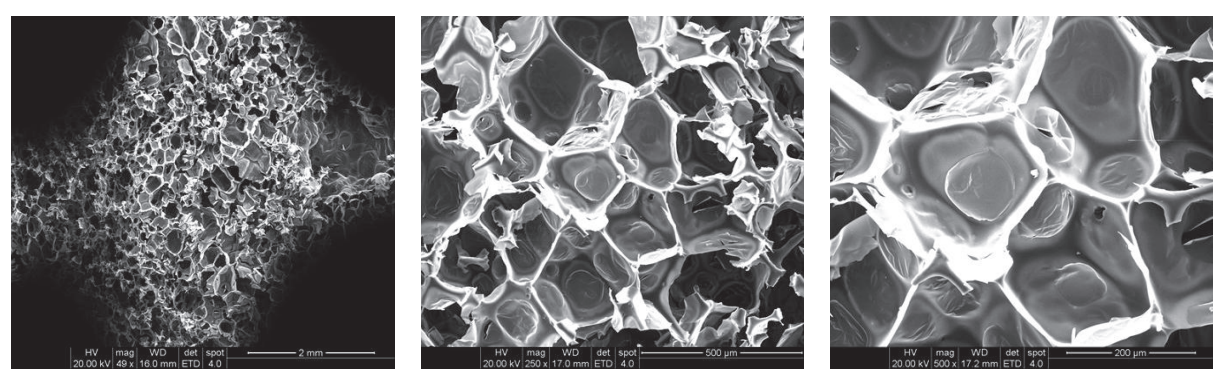

(b)
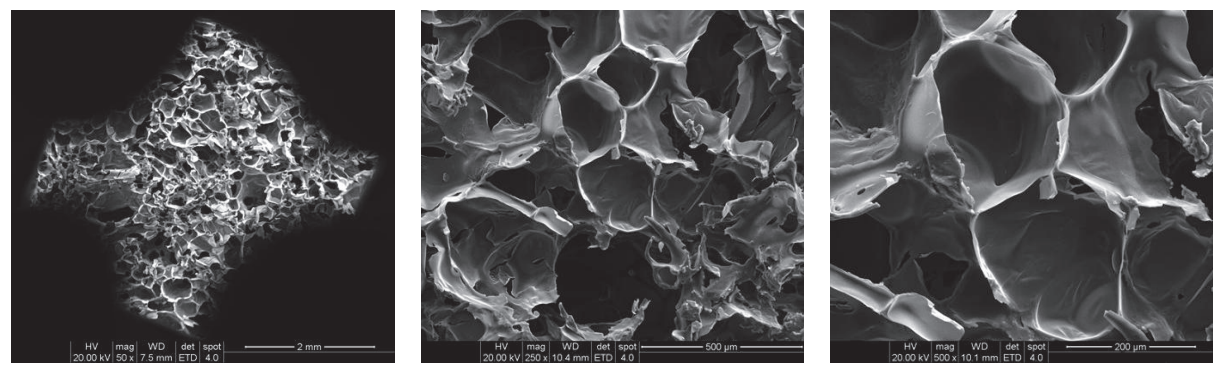

(c)
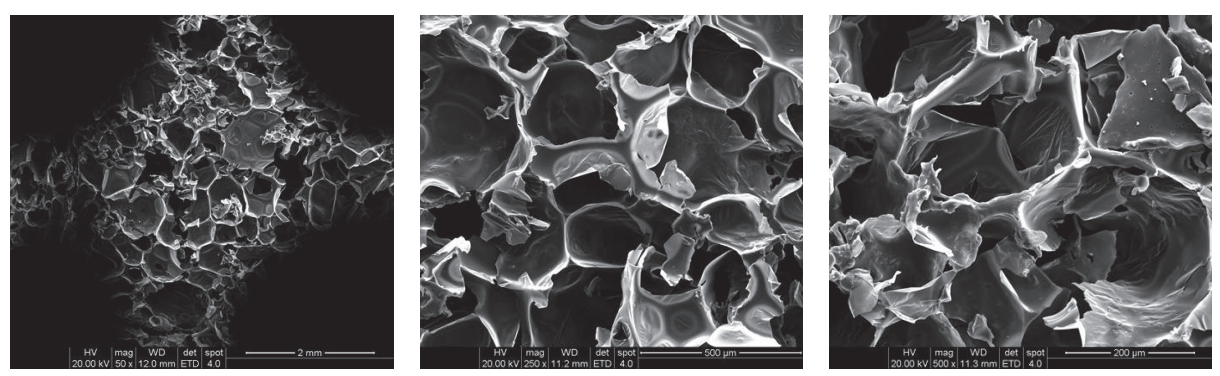

(d)
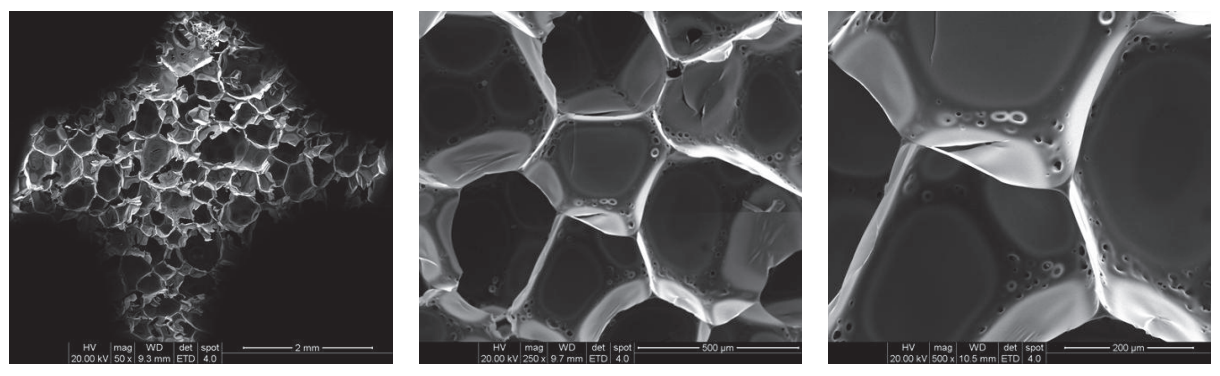

(e)

FIGURE 5: SEM photos of MFCG samples ((a) 10\%, (b) 30\%, (c) 50\%, (d) 80\%, and (e) CPP). 

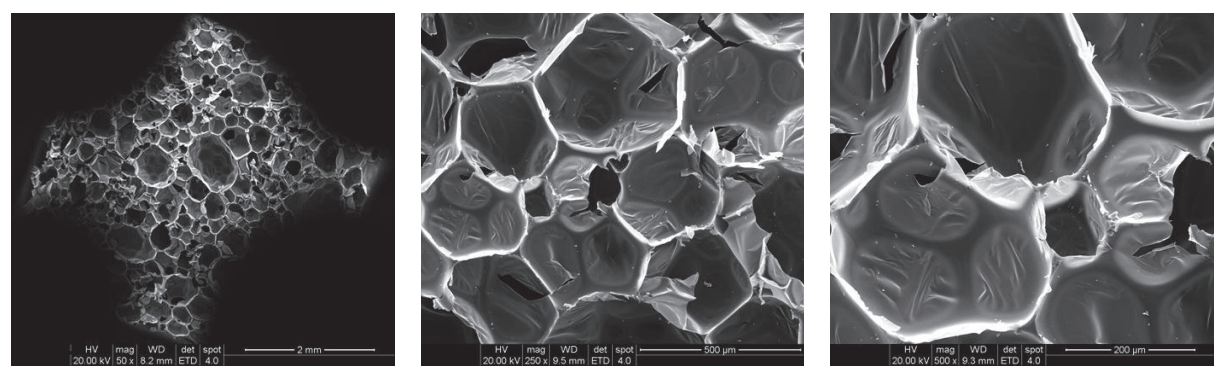

(a)
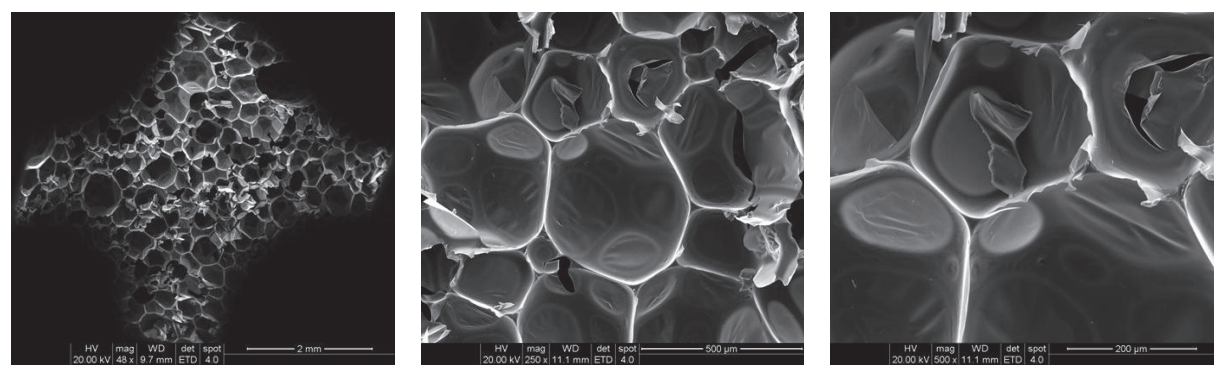

(b)
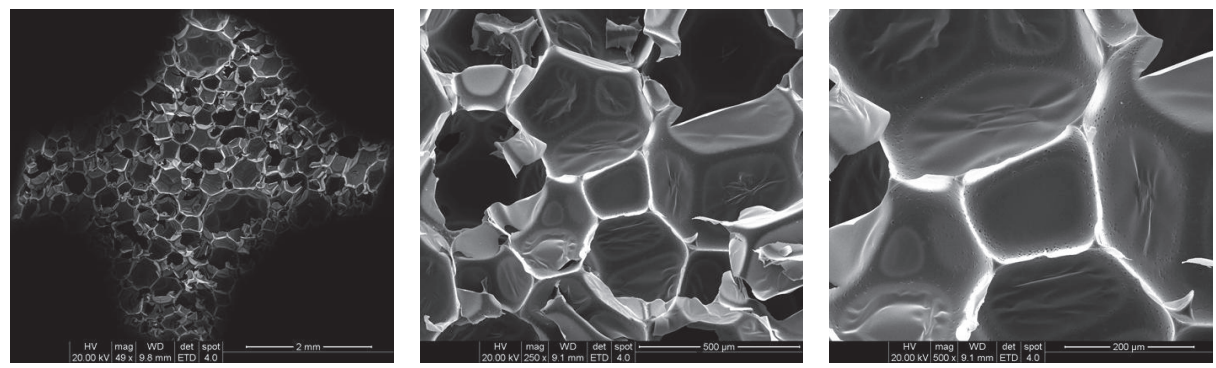

(c)
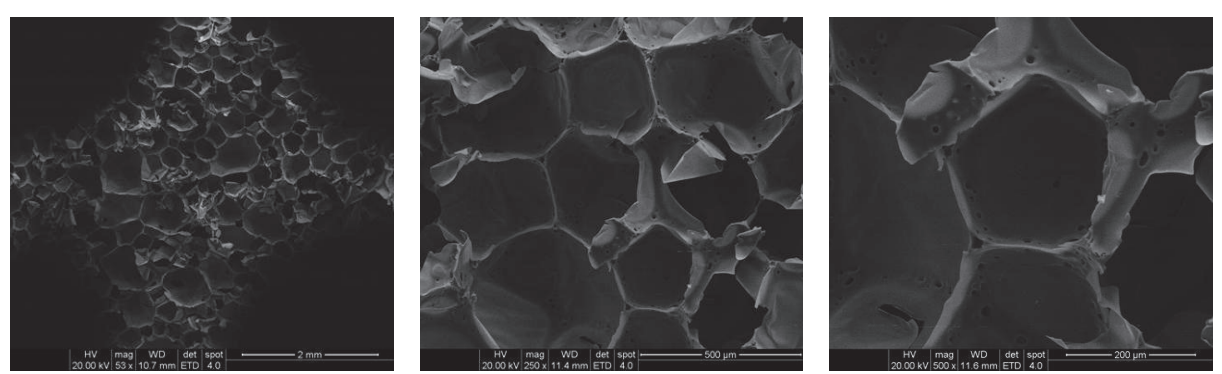

(d)
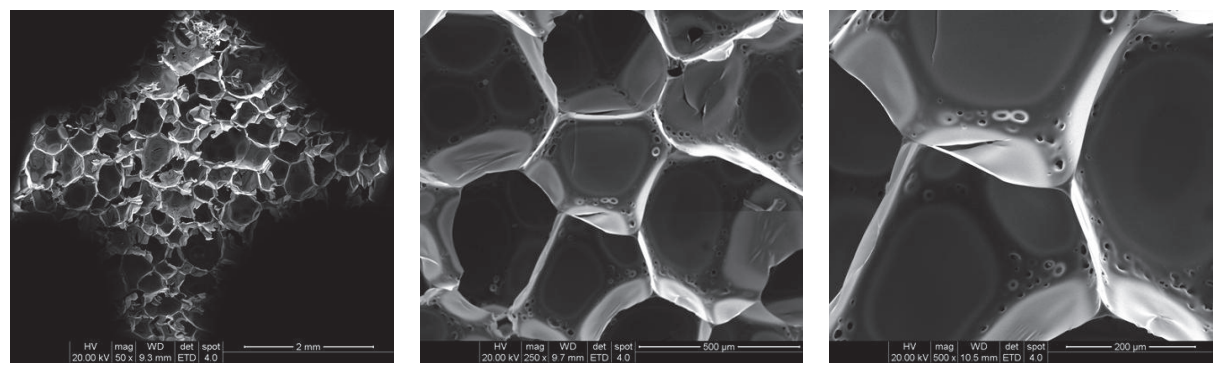

(e)

Figure 6: SEM photos of PG samples ((a) 10\%, (b) 30\%, (c) 50\%, (d) 80\%, and (e) CPP). 


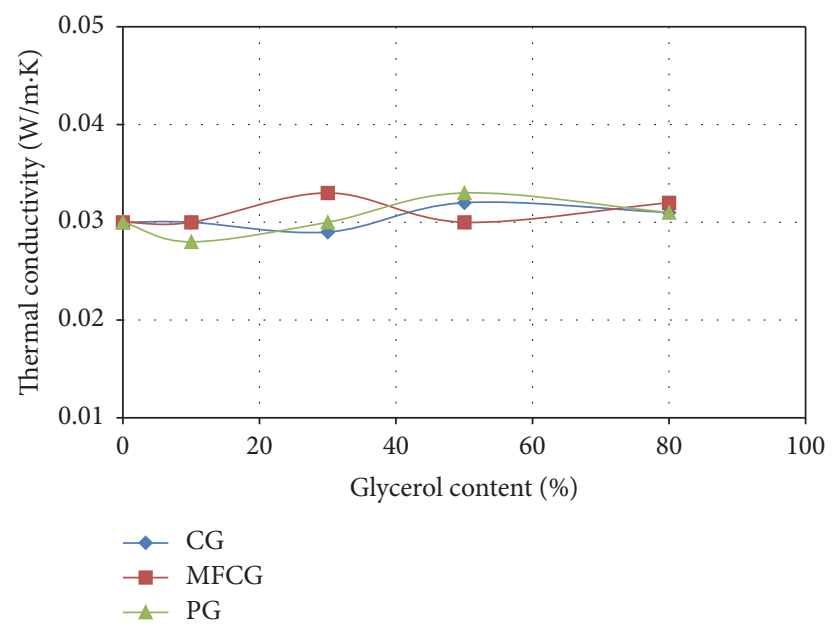

FIgURE 7: Thermal conductivity values for all PUF samples (PUF with commercial polyether polyol: $0,030 \mathrm{~W} / \mathrm{m} \cdot \mathrm{K})$.

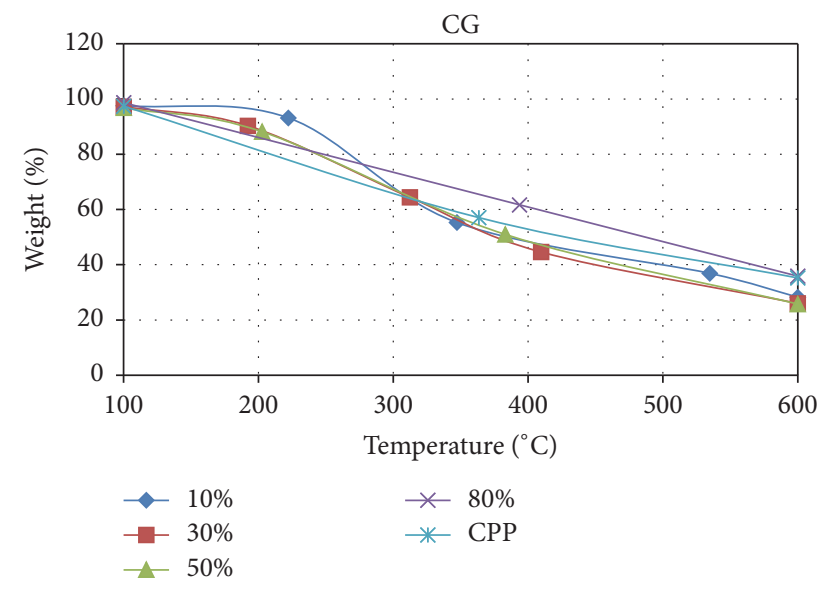

FIgURE 8: TGA results for all PUF samples with crude glycerol.

values increased with polyglycerol content increased, 0,0258 $\pm 0,0007$ and $0,0326 \pm 0,0006 \mathrm{~W} / \mathrm{m} \cdot \mathrm{K}$, respectively. Thermal conductivity values of all samples, with CG, MFCG, and PG, were higher than commercial PUF.

$\mathrm{Hu}$ and $\mathrm{Li}$ (2014) produced polyols and polyurethane foams by two-step sequential liquefaction of lignocellulosic biomass using crude glycerol as a liquefaction solvent [42]. They prepared three types of PUF and their thermal conductivity values were from $0,0322 \pm 0,0017 \mathrm{~W} / \mathrm{m} \cdot \mathrm{K}$ to $0,0389 \pm$ $0,0053 \mathrm{~W} / \mathrm{m} \cdot \mathrm{K}$. In this study, the thermal conductivity values of all samples were measured lower than $0,032 \mathrm{~W} / \mathrm{m} \cdot \mathrm{K}$ in spite of no liquefaction process.

The thermal conductivity values were observed from 0,0333 to $0,0408 \mathrm{~W} / \mathrm{m} \cdot \mathrm{K}$ by Dang et al. (2016) [44]. In this research, they were from 0,028 to $0,033 \mathrm{~W} / \mathrm{m} \cdot \mathrm{K}$ without polyol synthesis and extra method.

3.5. Thermogravimetric Analysis (TGA). Figures 8, 9, and 10 show that the combination of TGA results of the PUF formed

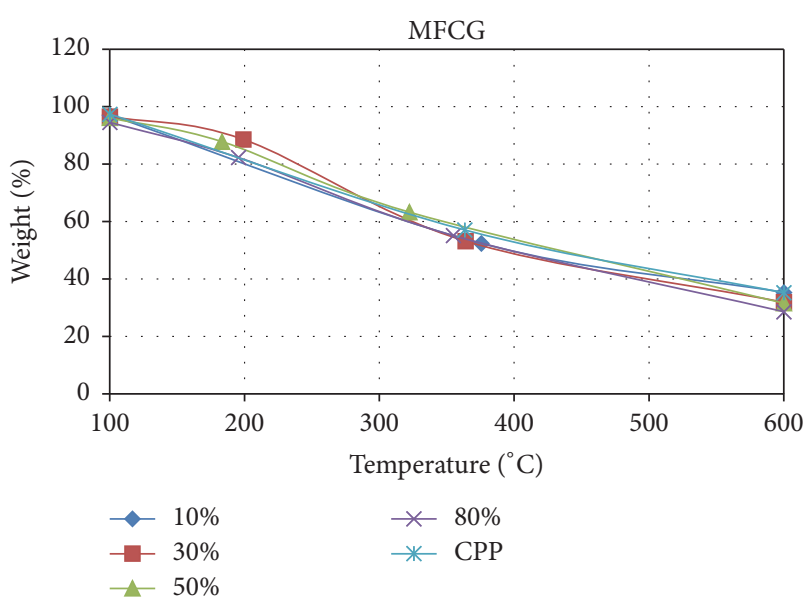

FIGURE 9: TGA results for all PUF samples with methanol-free crude glycerol.

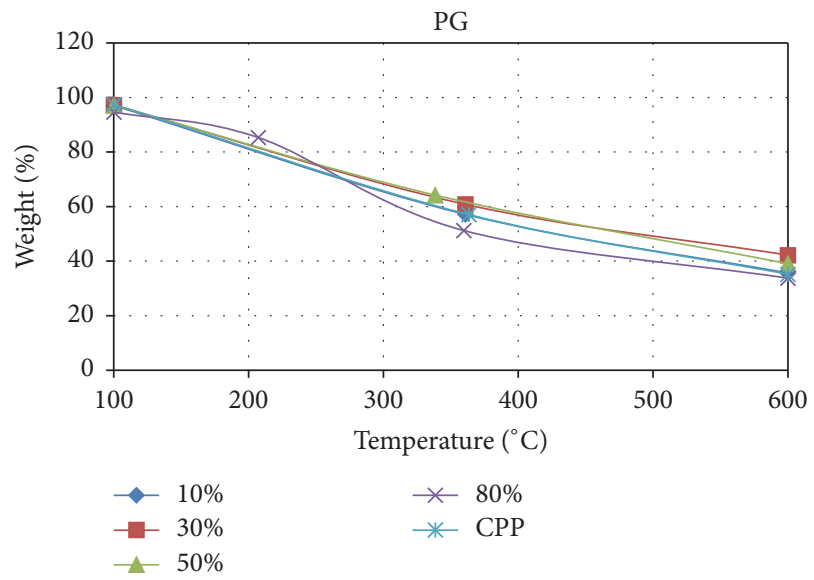

FIGURE 10: TGA results for all PUF samples with pure glycerol.

with crude glycerol, methanol-free crude glycerol, and pure glycerol, respectively.

For CG samples, thermal stabilities and residues left after heating are different from commercial PUF, because of their irregular structures and undesirable gas formation due to the methanol content. On the other hand, thermal stabilities of PUF with preparation of MFCG samples are similar to CPP. In addition, the graph of MFCG-10 is the same as CPP. The thermal stabilities of PG samples did not change much, except PG-80. The graph of PG-10 is also the same as CPP; and lines are overlapping. CG, MFCG, and PG values are 25-35\%, 29$35 \%$, and $33-42 \%$, respectively. For CG and MFCG samples, residues increase with increasing glycerol ratio as $\mathrm{CG}$ and MFCG are mixture and have impurities.

For CPP, the onset of thermal degradation occurs at $220^{\circ} \mathrm{C}$, and the maximum rate of degradation for the two main decomposition steps occurs at $\sim 340^{\circ} \mathrm{C}$ and $540^{\circ} \mathrm{C}$ (Figure 11).

CG-10 and CG-30 have three degradation steps at $200^{\circ} \mathrm{C}, 340^{\circ} \mathrm{C}$, and $480^{\circ} \mathrm{C}$, like CPP. However, other CG samples have two degradation samples at $\sim 200^{\circ} \mathrm{C}$ and $350^{\circ} \mathrm{C}$. 



FIGURE 11: TGA/DTG curves of CPP.
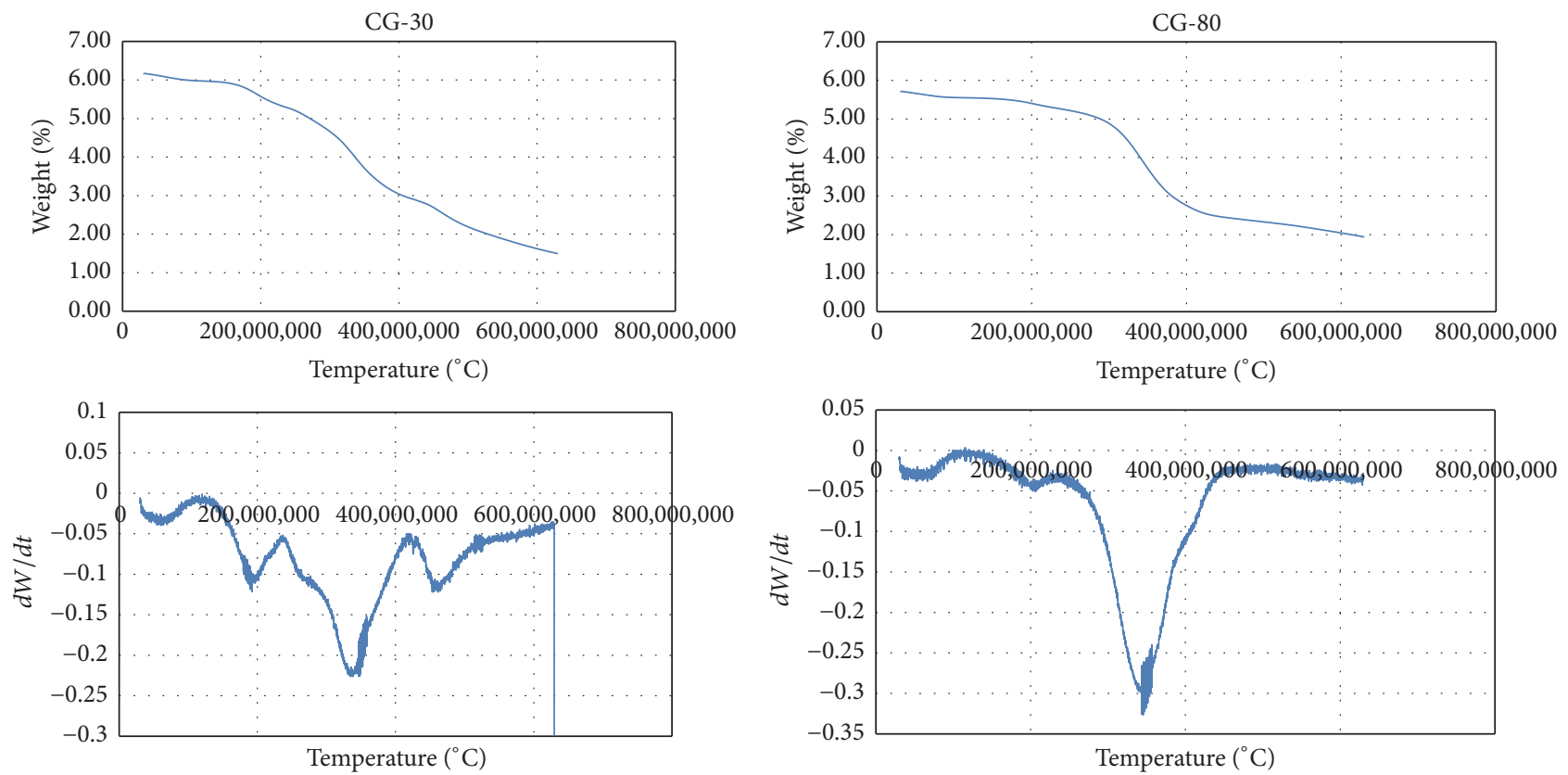

Figure 12: TGA/DTG curves of CG-30 and CG-80.

The onset temperatures of CG samples are lower than CPP due to the methanol elimination at about $180^{\circ} \mathrm{C}$. Figure 12 shows TGA and DTG curves of CG-30 and CG-80.

For MFCG samples, there are two degradation steps. The onset of thermal degradation occurs at $\sim 210^{\circ} \mathrm{C}$, and the maximum is at $\sim 340^{\circ} \mathrm{C}$. TGA and DTG curves of MFCG samples are similar to the CG samples. Therefore, they contain methanol less than CG. The TGA curves of PG samples are similar to CPP, but they have two degradation steps at $\sim 215^{\circ} \mathrm{C}$ and $340^{\circ} \mathrm{C}$. These two different values show that there are two different weight reductions in samples. First degradation is related to the breakage in urethane bonds, while the second step is related to the thermal decomposition of polyol. In the study of Zhao et al. (2012), PU foams prepared from liquefied mountain pine showed two stages of degradation that occurred at around 250 and $400^{\circ} \mathrm{C}$, respectively [43].
Figure 13 shows TGA and DTG curves of MFCG-10 and PG50.

According to these results, it can be concluded that the thermal stability of the polyurethane foams increases by increasing the purity of glycerol.

\section{Conclusion}

It is concluded from the results of this research that the glycerol can be used for PUF production as a polyol. The mechanical and thermal properties of PUF have increased with the purity of glycerol. However, these properties decreased with the glycerol content in polyol mixture increase. For all types of glycerol, $10 \%$ of glycerol-polyol mixture is similar to the commercial polyol. 30\% mixing ratio has also acceptable results for MFCG and PG, except CG because of methanol 

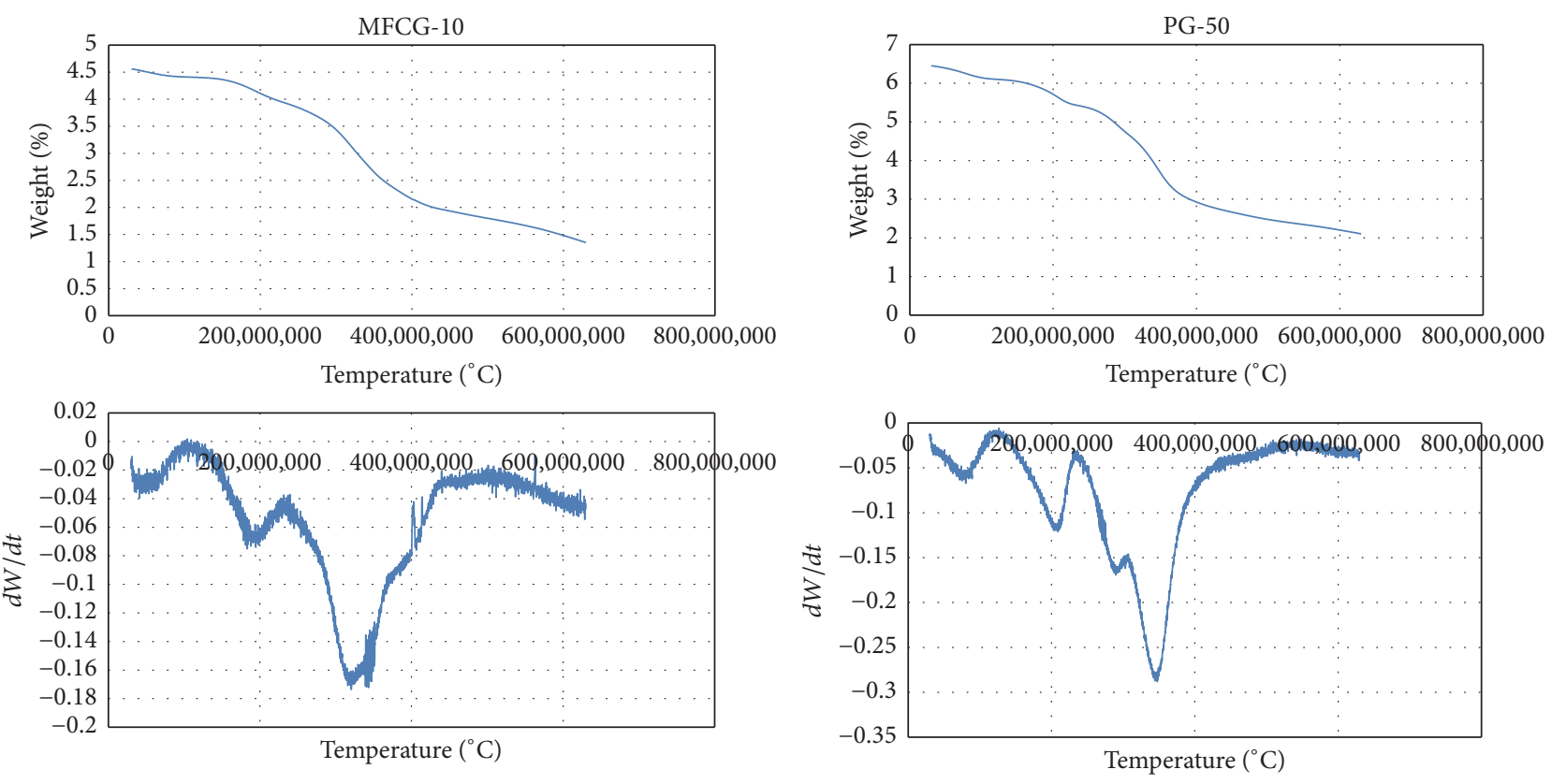

FIGURE 13: TGA/DTG curves of MFCG-10 and PG-50.

content. PUF reaction is exothermic so the methanol is evaporated, and that is why it affected the cell structure. The cell structure is one of the most important characteristics for the PUF which is used as thermal insulator.

In the previous studies, crude glycerol was used to prepare the polyol. As a result of this study, MFCG will be used to produce biopolyols; comparing the mechanical and thermal values of CG and MFCG, MFCG is more effective than CG.

This study identifies the critical aspects of polyurethane foam production by new uses of crude glycerol and methanolfree crude glycerol that are byproducts of biodiesel industry. And then, these byproducts have value addition with this study.

In addition, cup foaming method was used in this study. The cup foaming method is basic; other methods should be used to get more details. And, only tertiary amine catalyst and its cocatalyst were used for preparation. If tin catalyst is also used for reaction between polyol and diisocyanate, FTIR results will be different. According to SEM results, for CG and MFCG, the amounts of surfactant should be higher than $2 \%$ to organize the cell structure more precisely.

Seydibeyoğlu et al. (2013) prepared green polyurethane nanocomposites with soy polyol and bacterial nanocellulose as nanofiller [52]. It was observed that bacterial cellulose nanofibrils were reinforced to polyurethane matrix, which was $100 \%$ soy polyol based. The flexural strength values of green polyurethane nanocomposites increased over the unfilled samples by $100 \%$ and $50 \%$. In this study, the compression strength values were higher than the commercial PUF. However, the bacterial nanocellulose or nanofiller can be used in further studies to reinforce polyurethane foams, especially for crude glycerol based polyurethane foams.

\section{Disclosure}

The preliminary results of this research were presented before as an abstract in the 1st International Porous and Powder Materials Symposium and Exhibition PPM 2013.

\section{Competing Interests}

The authors declare that there is no conflict of interests regarding the publication of this paper.

\section{Acknowledgments}

The authors would like to express their deep thanks to Dr. Elif Alyamaç Seydibeyoğlu for giving direction to their research and valuable comments to progress during this study. They wish to thank Research Assistant Caner Karakaya from Material Science and Engineering of Celal Bayar University for gas chromatography of methanol-free crude glycerol and crude glycerol. Izmir Katip Celebi University scientific research project, BAP 2013-2-FMBP-42, is greatly acknowledged. And finally they would like to thank Poliser PU, Flokser Group, and DB Agricultural Energy Co. for supplying the raw materials during this study.

\section{References}

[1] K. Ashida, Polyurethane and Related Foams, CRC Press, 2006.

[2] ASTM Standard D16-00: Technology for paint, related coatings, materials, and applications, 2000.

[3] D. Dieterich, E. Grigat, W. Hahn, H. Hespe, and H. G. Schmelzer, "Principles of polyurethane chemistry and special applications," in Polyurethane Handbook, G. Oertel, Ed., pp. 11-53, Hanser Publishers, Munich, Germany, 1993. 
[4] D. K. Chattopadhyay and K. V. S. N. Raju, "Structural engineering of polyurethane coatings for high performance applications," Progress in Polymer Science (Oxford), vol. 32, no. 3, pp. 352-418, 2007.

[5] A. S. Chawla, D. ChoiniÈre, and I. Hinberg, "Laboratory analysis of reported failures of intra-aortic balloon catheters," Journal of Clinical Engineering, vol. 19, no. 3, pp. 209-217, 1994.

[6] M. Chen, D.-L. Zhou, Y. Chen, and P.-X. Zhu, "Analyses of structures for a synthetic leather made of polyurethane and microfiber," Journal of Applied Polymer Science, vol. 103, no. 2, pp. 903-908, 2007.

[7] A. J. Coury, K. E. Cobian, P. T. Cahalan, and A. H. Jevne, "Biomedical uses of polyurethanes," Advances in Urethane Science and Technology, vol. 9, pp. 130-168, 1984.

[8] N. Dowidar, H. J. Kolmos, and P. Matzen, "Experimental clogging of biliary endoprostheses. Role of bacteria, endoprosthesis material, and design," Scandinavian Journal of Gastroenterology, vol. 27, no. 1, pp. 77-80, 1992.

[9] J. P. Ferriter, C. E. Meyers Jr., and L. Lorton, "The effect of hydrogen ion concentration on the force-degradation rate of orthodontic polyurethane chain elastics," American Journal of Orthodontics and Dentofacial Orthopedics, vol. 98, no. 5, pp. 404-410, 1990.

[10] D. Graiver, R. L. Durall, and T. Okada, "Surface morphology and friction coefficient of various types of Foley catheter," Biomaterials, vol. 14, no. 6, pp. 465-469, 1993.

[11] D. J. Hirsch, P. Bergen, and K. K. Jindal, "Polyurethane catheters for long-term hemodialysis access," Artificial Organs, vol. 21, no. 5, pp. 349-354, 1997.

[12] M. Ionescu, Chemistry and Technology of Polyols for Polyurethanes, Rapra Technology, Shawbury, UK, 2005.

[13] B. Jansen, L. P. Goodman, and D. Ruiten, "Bacterial adherence to hydrophilic polymer-coated polyurethane stents," Gastrointestinal Endoscopy, vol. 39, no. 5, pp. 670-673, 1993.

[14] G. Jayasree and C. P. Sharma, "Polyether urethane urea membrane for an improved hemodialysis," Biomaterials, Artificial Cells and Immobilization Biotechnology, vol. 19, no. 3, pp. 649659, 1991.

[15] S. Q. Liu and M. Kodama, "Porous polyurethane vascular prostheses with variable compliances," Journal of Biomedical Materials Research, vol. 26, no. 11, pp. 1489-1502, 1992.

[16] E. M. H. Mathus-Vliegen, G. N. J. Tytgat, and M. P. Merkus, "Feeding tubes in endoscopic and clinical practice: the longer the better?" Gastrointestinal Endoscopy, vol. 39, no. 4, pp. 537$542,1993$.

[17] U. Meier-Westhues, Polyurethanes Coatings, Adhesives and Sealants, Vincentz Network, Hannover, Germany, 2007.

[18] I. Nissenkorn and M. Shalev, "Polyurethane stent for treatment of urethral strictures," Journal of Endourology, vol. 11, no. 6, pp. 481-483, 1997.

[19] D. Randall and S. Lee, The Polyurethanes Book, John Wiley \& Sons, 2003.

[20] C. J. Sollerman and M. Geijer, "Polyurethane versus silicone for endoprosthetic replacement of the metacarpophalangeal joints in rheumatoid arthritis," Scandinavian Journal of Plastic and Reconstructive Surgery and Hand Surgery, vol. 30, no. 2, pp. 145150, 1996.

[21] M. Szycher, "Biostability of polyurethane elastomers: a critical review," Journal of Biomaterials Applications, vol. 3, no. 2, pp. 297-402, 1988.
[22] M. Szycher, Szycher's Handbook of Polyurethanes, CRC Press Taylor \& Francis, Boca Raton, Fla, USA, 2nd edition, 2012.

[23] P. Vermette, H. J. Griesser, G. Laroche, and R. Guidoin, Biomedical Applications of Polyurethanes, Landes Bioscience/Eurekah .com, New York, NY, USA, 2001.

[24] N. R. Vyavahare, W. Chen, R. R. Joshi et al., "Current progress in anticalcification for bioprosthetic and polymeric heart valves," Cardiovascular Pathology, vol. 6, no. 4, pp. 219-229, 1997.

[25] Z. W. Wicks, F. N. Jones, S. P. Pappas, and D. A. Wicks, Organic Coatings: Science and Technology, Wiley-Interscience, Hoboken, NJ, USA, 2007.

[26] Modern Plastic Encyclopedia, McGraw Hill, New York, NY, USA, 1998.

[27] Manufacturing Handbook \& Buyers' Guide: Plastic Technology, New York, 1997-1998.

[28] C. A. Cateto, M. F. Barreiro, and A. E. Rodrigues, "Monitoring of lignin-based polyurethane synthesis by FTIR-ATR," Industrial Crops and Products, vol. 27, no. 2, pp. 168-174, 2008.

[29] C. A. Cateto, M. F. Barreiro, A. E. Rodrigues, and M. N. Belgacem, "Optimization study of lignin oxypropylation in view of the preparation of polyurethane rigid foams," Industrial \& Engineering Chemistry Research, vol. 48, no. 5, pp. 2583-2589, 2009.

[30] H. Dai, L. Yang, B. Lin, C. Wang, and G. Shi, "Synthesis and characterization of the different soy-based polyols by ring opening of epoxidized soybean oil with methanol, 1,2ethanediol and 1,2-propanediol," Journal of the American Oil Chemists' Society, vol. 86, no. 3, pp. 261-267, 2009.

[31] D. V. Evtuguin, J. P. Andreolety, and A. Gandini, "Polyurethanes based on oxygen-organosolv lignin," European Polymer Journal, vol. 34, no. 8, pp. 1163-1169, 1998.

[32] T. Hatakeyama, Y. Izuta, S. Hirose, and H. Hatakeyama, "Phase transitions of lignin-based polycaprolactones and their polyurethane derivatives," Polymer, vol. 43, no. 4, pp. 1177-1182, 2002.

[33] Y. Jin, X. Ruan, X. Cheng, and Q. Lü, "Liquefaction of lignin by polyethyleneglycol and glycerol," Bioresource Technology, vol. 102, no. 3, pp. 3581-3583, 2011.

[34] T. T. M. Tan, “Cardanol-lignin-based polyurethanes," Polymer International, vol. 41, no. 1, pp. 13-16, 1996.

[35] J.-P. Latere Dwan'isa, A. K. Mohanty, M. Misra, L. T. Drzal, and M. Kazemizadeh, "Biobased polyurethane and its composite with glass fiber," Journal of Materials Science, vol. 39, no. 6, pp. 2081-2087, 2004.

[36] M. N. S. Kumar, A. K. Mohanty, L. Erickson, and M. Misra, "Lignin and its applications with polymers," Journal of Biobased Materials and Bioenergy, vol. 3, no. 1, pp. 1-24, 2009.

[37] J. Van Gerpen, B. Shanks, R. Pruszko, D. Clements, and G. Knothe, Biodiesel Production Technology, National Renewable Energy Laboratory, 2002-2004.

[38] J. Van Gerpen, "Biodiesel processing and production," Fuel Processing Technology, vol. 86, no. 10, pp. 1097-1107, 2005.

[39] G. Assman, G. Blasey, B. Gutsche, L. Jeromin Rigal Jr., R. Armengand, and B. Cormary, "Continuous progress for the production of lower alkyl esters," US Patent No. 5,514,820, 1996.

[40] W. D. Stidham, D. W. Seaman, and M. F. Danzer, "Method for preparing a lower alkyl ester product from vegetable oil," US Patent no. 6,127,560, 2000.

[41] T. Wimmer, "Progress for the production of fatty acid esters of lower alcohols," US Patent No. 5,399,731, 1995. 
[42] S. Hu and Y. Li, "Two-step sequential liquefaction of lignocellulosic biomass by crude glycerol for the production of polyols and polyurethane foams," Bioresource Technology, vol. 161, pp. 410-415, 2014.

[43] Y. Zhao, N. Yan, and M. Feng, "Polyurethane foams derived from liquefied mountain pine beetle-infested barks," Journal of Applied Polymer Science, vol. 123, no. 5, pp. 2849-2858, 2012.

[44] Y. Dang, X. Luo, F. Wang, and Y. Li, "Value-added conversion of waste cooking oil and post-consumer PET bottles into biodiesel and polyurethane foams," Waste Management, vol. 52, pp. 360366, 2016.

[45] R. C. S. Araújo, V. M. D. Pasa, and B. N. Melo, "Effects of biopitch on the properties of flexible polyurethane foams," European Polymer Journal, vol. 41, no. 6, pp. 1420-1428, 2005.

[46] Ł. Piszczyk, M. Strankowski, M. Danowska, J. T. Haponiuk, and M. Gazda, "Preparation and characterization of rigid polyurethane-polyglycerol nanocomposite foams," European Polymer Journal, vol. 48, no. 10, pp. 1726-1733, 2012.

[47] A. Zlatanić, C. Lava, W. Zhang, and Z. S. Petrović, "Effect of structure on properties of polyols and polyurethanes based on different vegetable oils," Journal of Polymer Science, Part B: Polymer Physics, vol. 42, no. 5, pp. 809-816, 2004.

[48] X. Luo, S. Hu, X. Zhang, and Y. Li, “Thermochemical conversion of crude glycerol to biopolyols for the production of polyurethane foams," Bioresource Technology, vol. 139, pp. 323-329, 2013.

[49] A. A. Septevani, D. A. C. Evans, C. Chaleat, D. J. Martin, and P. K. Annamalai, "A systematic study substituting polyether polyol with palm kernel oil based polyester polyol in rigid polyurethane foam," Industrial Crops and Products, vol. 66, pp. 16-26, 2015.

[50] M. Arduini-Schuster, J. Manara, and C. Vo, "Experimental characterization and theoretical modeling of the infrared-optical properties and the thermal conductivity of foams," International Journal of Thermal Sciences, vol. 98, pp. 156-164, 2015.

[51] Ł. Piszczyk, M. Strankowski, M. Danowska, A. Hejna, and J. T. Haponiuk, "Rigid polyurethane foams from a polyglycerolbased polyol," European Polymer Journal, vol. 57, pp. 143-150, 2014.

[52] M. Ö. Seydibeyoğlu, M. Misra, A. Mohanty et al., "Green polyurethane nanocomposites from soy polyol and bacterial cellulose," Journal of Materials Science, vol. 48, no. 5, pp. 2167-2175, 2013. 

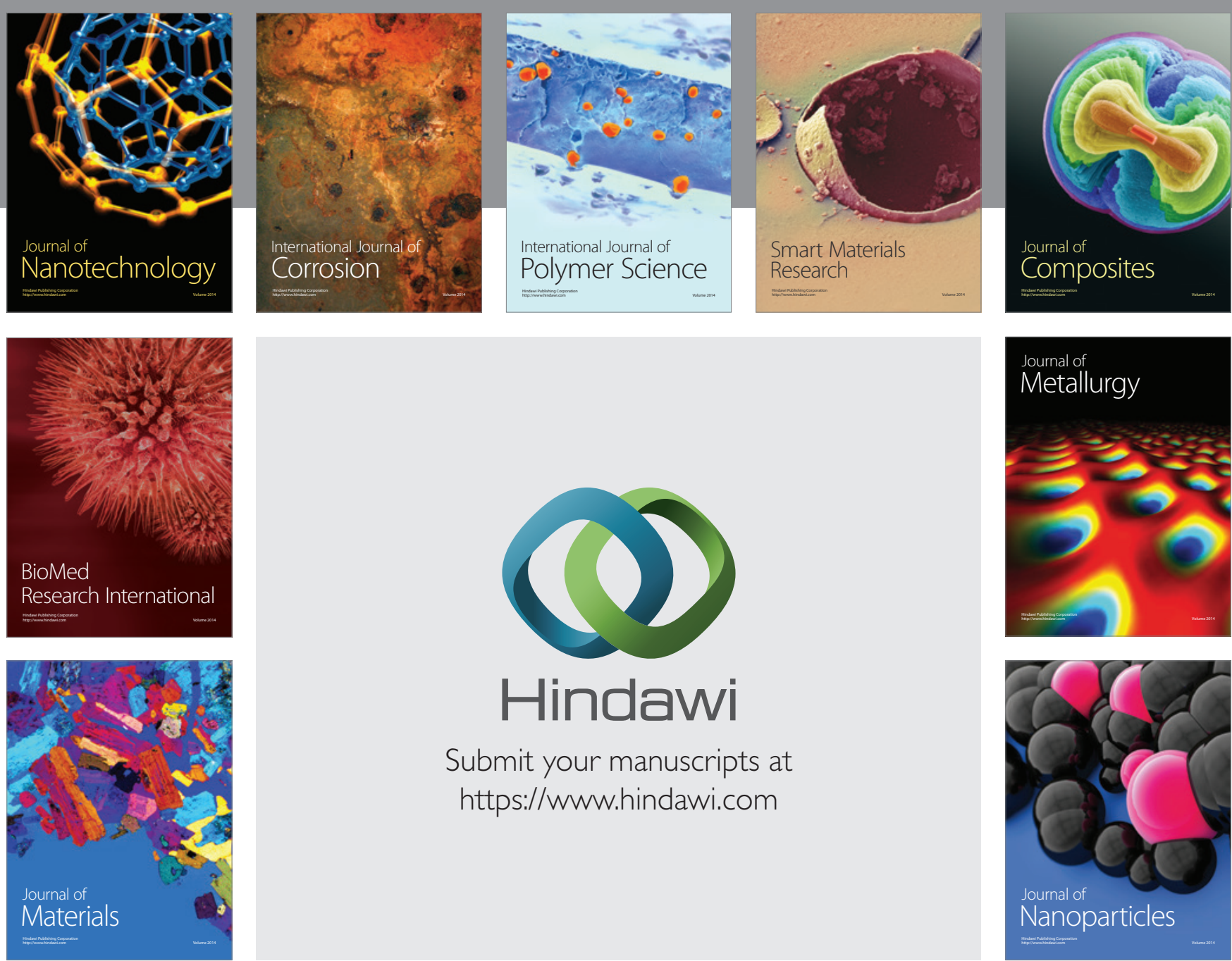

\section{Hindawi}

Submit your manuscripts at

https://www.hindawi.com

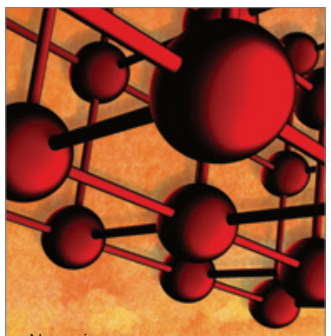

Materials Science and Engineering
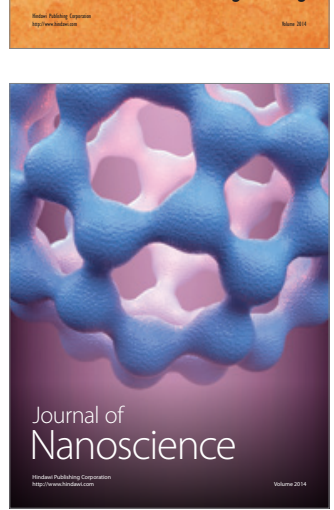
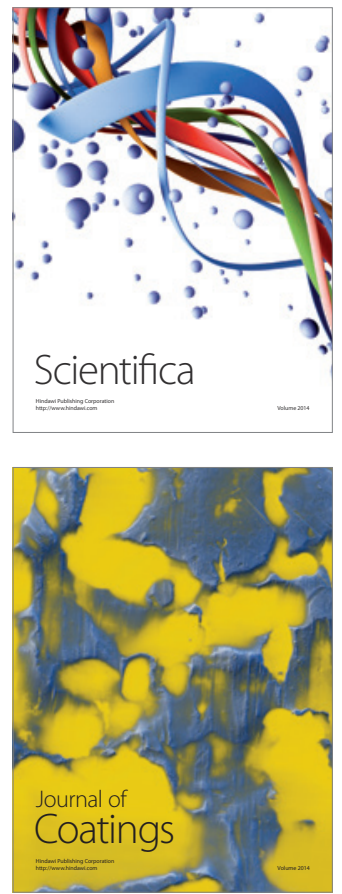
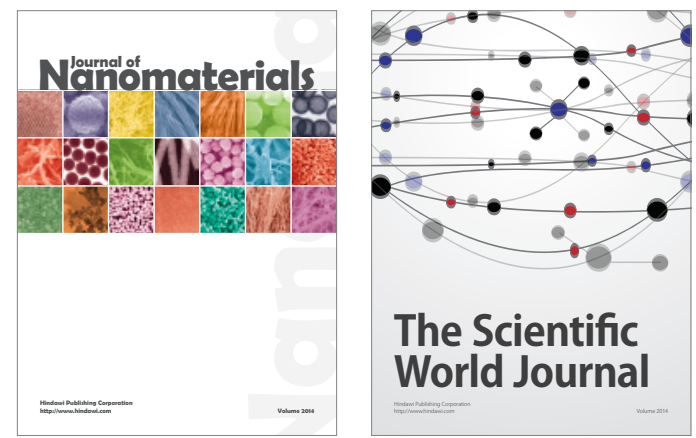

The Scientific World Journal
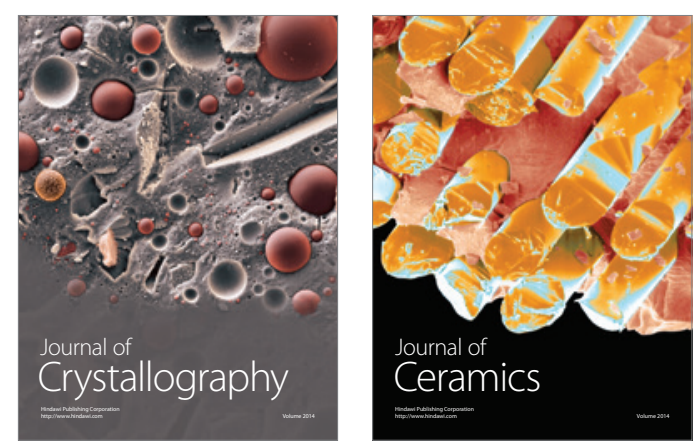
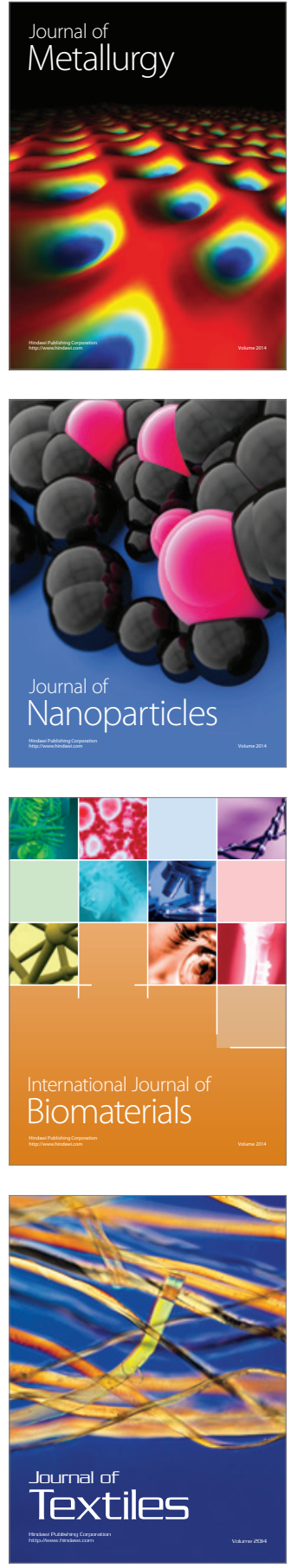